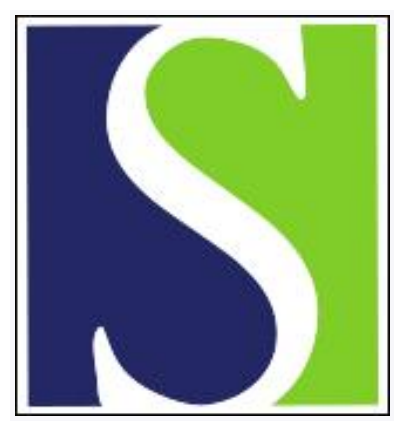

Scand J Work Environ Health 1978;4(2):114-121

https://doi.org/10.5271/sjweh.2716

Issue date: Jun 1978

Evaluation of occupational exposure to xylene by blood, exhaled air and urine analysis.

by Engström K, Husman K, Pfäffli P, Riihimäki V

Key terms: biological monitoring; blood analysis; exhaled air analysis; occupational exposure; urine analysis; xylene

This article in PubMed: www.ncbi.nlm.nih.gov/pubmed/684386

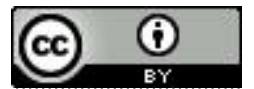




\title{
Evaluation of occupational exposure to xylene by blood, exhaled air and urine analysis
}

\author{
by KERSTIN ENGSTRÖM, M.Sc., ${ }^{1}$ KAJ HUSMAN, M.D.,2 PIRKKO PFÄFFLI, M.Sc., ${ }^{3}$
} and VESA RIIHIMÄKI, M.D., M.Sc. ${ }^{3}$

\begin{abstract}
ENGSTRÖM, K., HUSIMAN, K., PFÄFFLI, P. and RIIHIMÄKI, V. Evaluation of occupational exposure to xylene by blood, exhaled air and urine analysis. Scand. j. work environ. \& health 4 (1978) 114-121. Occupational xylene exposure in the breathing zone of 15 painters was measured during three consecutive workdays. The applicability of the use of different biological samples was tested by the monitoring of xylene concentrations in blood and exhaled air, and urinary methylhippuric acid excretion as well. The best relation to the time-weighted average of xylene exposure was obtained for urinary methylhippuric acid concentration at the end of the workday; an amount of $665 \mathrm{mg} / \mathrm{g}$ of creatinine corresponded to $50 \mathrm{ppm}$ of xylene. The amount of methylhippuric acid in a morning sample at the end of the work week, on the other hand, correlated to the mean exposure of the three preceding days. Xylene concentrations in exhaled air and blood sampled after the workday correlated poorly to the exposure of the preceding day. The urinary elimination of methylhippuric acid after the finished work week showed two distinct phases of excretion, with different biological half-times (1.9-5.3 $\mathrm{h}$ for the first $10 \mathrm{~h}$ after exposure and 16.5-48.4 $\mathrm{h}$ for the next two days).
\end{abstract}

Key words: biological monitoring, occupational exposure, xylene.

Commercial xylene, a mixture of $\mathrm{o}^{-}, \mathrm{m}-$ and $p$-isomers, with the metaform as the principal component, is extensively used in industry. In 1976 the import of xylene to Finland amounted to 17,500 t, which is about $10 \%$ of the total amount of solvents imported and/or produced (10). About $15 \%$ of the xylene is used as a component in paints and thinners. Xylene often constitutes the main part of the solvent mixture.

When painters' exposure to solvents is evaluated, the concentration of the parent

1 Turku Regional Institute of Occupational Health, Turku, Finland.

2 Kuopio Regional Institute of Occupational Health, Kuopio, Finland.

3 Department of Industrial Hygiene and Toxicology, Institute of Occupational Health, Helsinki, Finland.

Reprint requests to: Ms. Kerstin Engström, Turku Regional Institute of Occupational Health, Hämeenkatu 10, SF-20500 Turku 50, Finland. compound in the ambient air, in the blood, and in the exhaled air or the excretion of a metabolite into the urine can be determined. Each of these methods has its own advantages and limitations. When the most useful parameter is being selected, the physicochemical and the biochemical properties (volatility, tissue solubility, metabolic rate, etc.) of the individual solvent must be taken into account. Xylene is highly soluble in blood and tissues, but undergoes significant biotransformation, producing methylhippuric acid, which is rapidly excreted in the urine (8). In the biological control of occupational xylene exposure, the determination of xylene concentration in both the blood and the exhaled air and an analysis of the urinary metabolite can be employed. Measurement of methylhippuric acid as an indicator of occupational xylene exposure has been proposed $(5,6)$, and the method has been tested in experimental conditions by Sedivec and Flek (9). 
In the present study we measured o-, $\mathrm{m}$ - and $\mathrm{p}$-xylene concentrations in the environmental air from the breathing zone of 15 painters during three consecutive workdays. Simultaneously, biological monitoring was carried out with the measurement of concentrations of $\mathrm{o}-, \mathrm{m}$ and p-xylene in blood and exhaled air, as well as the concentration of $\mathrm{m}$ - and $\mathrm{p}$ methylhippuric acids in urine. The relationships between the different parameters (blood, exhaled air and urine) and the time-weighted average (TWA) of xylene exposure were analyzed, and their applicability in occupational health practice has been discussed. The choice of appropriate sampling times was tested so that a differentiation between acute uptake and prolonged loading could be made. Furthermore, the urinary excretion rate of methylhippuric acid was determined from the methylhippuric acid concentrations, followed from Friday afternoon to Monday morning after the termination of exposure.

\section{MATERIAL AND METHODS}

\section{Subjects}

Fifteen subjects (1 female and 14 males, aged 18 to 63 years), who represented five different workshops, were studied. Their body heights ranged from 160 to $183 \mathrm{~cm}$ and body weights from 55 to $85 \mathrm{~kg}$. According to Ciba scientific tables (2), one subject was classified as slim, eleven as being of normal weight and three as obese; none of the subjects were excessively overweight. The workers used different methods of painting, i.e., spraying, curtain coating, and dipping. The percentage of xylene in the solvent mixture of the paints employed varied from 15 to almost $100 \%$ (table 1). All the subjects were requested to limit their alcohol consumption to very moderate amounts during the investigation.

\section{Exposure}

The measurements were performed on three consecutive workdays (Wednesday to Friday). We measured xylene in the ambient air by collecting air from the breathing zone of the painters through charcoal sampling tubes with personal sampling pumps (Sipin, SP-1) for 0.5-h periods over the whole workday. The xylene adsorbed was desorbed with dimethylformamide and analyzed by gas chromatography (Perkin Elmer Ltd., Model F-11, FID). A glass column (length $200 \mathrm{~cm}$, internal diameter $0.32 \mathrm{~cm}$ ) was used, and the column was packed with Chromosorb $P$ (80/100 mesh), coated with $10 \%$ Carbowax $20 \mathrm{M}$. The temperatures were as follows: oven $90^{\circ} \mathrm{C}$, injector $130^{\circ} \mathrm{C}$, and detector $130^{\circ}$ C. Nitrogen $(30 \mathrm{ml} / \mathrm{min})$ was used as the carrier gas. The analysis included all isomers. Time-weighted average (TWA) concentrations were estimated from individual 0.5-h samples for each day. The total daily work time varied from 6 to $8 \mathrm{~h}$; the lunchbreak and coffee breaks were not included.

\section{Blood sample collection and analysis}

Blood samples were obtained before the subjects started work and at the following time points after work: 5, 95, 185 and 965 min. Sampling was performed only on Wednesday. The samples were drawn from cubital veins. Xylene concentrations (all isomers) in the blood were determined with the head space technique and gas chromatography (3).

\section{Exhaled air sample collection and analysis}

The first exhaled air sample was collected just before the workshift, and the following ones at 2 - $h$ intervals during the shift, as well as $1-3,30,60,90,120,150$, 180,360 and $960 \mathrm{~min}$ after work. The samples were collected on Wednesday and Thursday. The method of collection and analysis has been described elsewhere (4).

\section{Urine sampling and analysis}

Urine was sampled daily at the beginning of the workshift, $3 \mathrm{~h}$ later, again at the end of the shift, and thereafter 4,8 and 
Table 1. Xylene concentration in ambient air in different workshops.

\begin{tabular}{|c|c|c|c|c|c|c|c|c|c|}
\hline \multirow{2}{*}{$\begin{array}{l}\text { Work- } \\
\text { shop }\end{array}$} & \multirow{2}{*}{$\begin{array}{l}\text { Painting } \\
\text { method } \\
\text { used }\end{array}$} & \multirow{2}{*}{$\begin{array}{l}\text { Xylene } \\
(\% / 0)\end{array}$} & \multirow{2}{*}{$\begin{array}{c}\text { Number } \\
\text { of } \\
\text { workers }\end{array}$} & \multicolumn{3}{|c|}{$\begin{array}{c}\text { Daily time-weighted average } \\
\text { of xylene }\left(\mathrm{cm}^{3} / \mathrm{m}^{3}\right)\end{array}$} & \multicolumn{3}{|c|}{$\begin{array}{l}\text { Xylene concentration in indi- } \\
\text { vidual } 0.5 \text {-h samples }\left(\mathrm{cm}^{3} / \mathrm{m}^{3}\right)\end{array}$} \\
\hline & & & & $\begin{array}{l}\text { Number } \\
\text { of days }\end{array}$ & Median & Range & $\begin{array}{c}\text { Number } \\
\text { of } \\
\text { samples }\end{array}$ & Median & Range \\
\hline \multirow{4}{*}{$\begin{array}{l}\mathrm{A} \\
\mathrm{B} \\
\mathrm{C} \\
\mathrm{D}\end{array}$} & Dipping & $\sim 100$ & 2 & 6 & 15 & $9-21$ & 90 & 6 & $1-340$ \\
\hline & Spraying & $15-50 \mathrm{a}$ & 3 & 9 & 21 & $4-40$ & 125 & 11 & $2-319$ \\
\hline & Spraying & $>50 \mathrm{~b}$ & 3 & 9 & 7 & $3-11$ & 135 & 4 & $1-59$ \\
\hline & coating & $\sim 100$ & 3 & 9 & 29 & $20-46$ & 123 & 24 & $3-211$ \\
\hline \multirow[t]{2}{*}{$\mathbf{E}$} & Electrostatic & & & & & & & & \\
\hline & dipping & $15-50 \mathrm{c}$ & 4 & 12 & 34 & $19-70$ & 58 & 38 & $8-207$ \\
\hline
\end{tabular}

a Also alcohols and esters.

b Also aliphatic hydrocarbons.

c Also aromatic hydrocarbons.

$15 \mathrm{~h}$ after the exposure was terminated. The collection of all urine continued from Friday afternoon over the weekend $(63 \mathrm{~h})$. Three subjects provided additional urine samples every Monday morning over a 3week period following a month's leave from xylene exposure. The amount of methylhippuric acids (sum of $\mathrm{m}$ - and $\mathrm{p}$ isomers) was determined according to the method of Engström et al. (3). The acids were hydrolyzed by alkaline hydrolysis, and the toluic acids obtained were silylated and analyzed by gas chromatography. The volume, pH, urinary density, and creatinine concentration (Jaffés color reaction) were measured for all samples.

\section{Statistical methods}

Biological half-times (time during which the concentration decreases by $50 \%$ ) were obtained by plotting methylhippuric acid concentrations on a semilogarithmic scale against time. Linear regression lines were calculated with the method of least square fitting and the halftimes estimated from the lines. The individual excretion curves for methylhippuric acid, obtained after termination of exposure, were grouped according to the preceding exposure level of xylene. The equations best fitting the observed data were calculated as follows:

$$
\ln \mathrm{C}=\mathrm{a}+\mathrm{b} \ln (\mathrm{t}+\mathrm{l}),
$$

where $\mathrm{C}=$ methylhippuric acid concentra- tion (mg/g creatinine), $\mathrm{t}=$ time after exposure (h), and $a$ and $b$ are constants.

As the inclinations of slope $b$ for the different curves are very similar, all equations were adjusted to a unit slope, representing the mean of the different $b$ values. The Pearson correlation coefficient (r) was calculated to delineate the relationships between urinary methylhippuric acid concentration and TWA xylene exposure.

\section{RESULTS}

\section{Ambient air concentrations}

The daily TWA concentrations of xylene varied from 3 to $70 \mathrm{~cm}^{3} / \mathrm{m}^{3}$ in the different workshops (table 1). Thus all the TWAs were below the present Finnish hygienic norm of $100 \mathrm{~cm}^{3} / \mathrm{m}^{3}$. Only a minor part $(<5 \%)$ of the individual $0.5-\mathrm{h}$ samples exceeded the hygienic norm (fig. 1).

\section{Exhaled air and blood concentrations}

Exhaled air concentrations during the workshift in relation to the corresponding ambient air levels of two workers are presented in fig. 2. The xylene concentration in the exhaled air amounted to $8 \%$, range 1 to $27 \%(\mathrm{~N}=75)$, of the mean level in the ambient air sample collected during the preceding $0.5-h$ period. The large vari- 


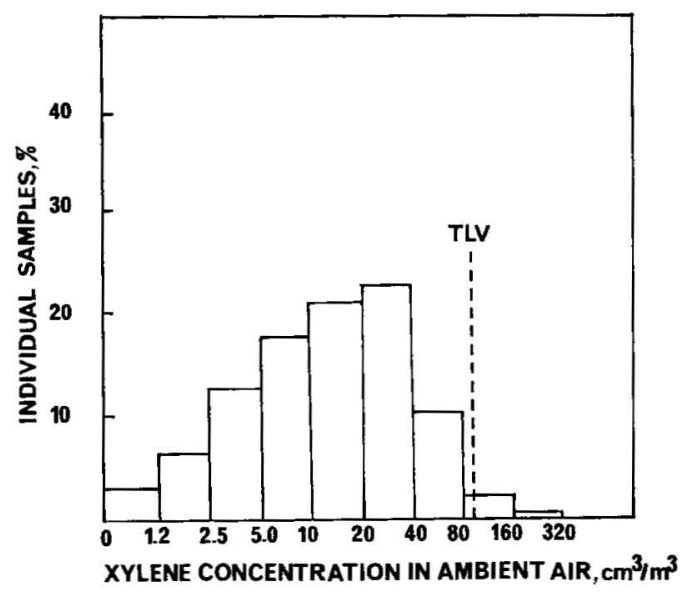

Fig. 1. Percentage distribution of airborne xylene concentration of the individual $0.5-\mathrm{h}$ samples taken from different workshops.

ation was due to the frequently remarkable fluctuation in the environmental air concentrations. The postexposure xylene concentrations in the blood and the exhaled air are presented in table 2 . In the blood, as well as in the exhaled air, the concentration of xylene decreased, quite rapidly in the course of 1 to $2 \mathrm{~h}$, thereafter more slowly over the $16 \mathrm{~h}$ followup period. The results in table 2 are grouped according to the measured environmental TWA concentrations of $x y-$ lene during the workday. There was a natural increase in the group mean of the xylene concentrations for blood and exhaled air as the TWA concentration increased. Individual values of the groups extensively overlapped, however. The length of time during which xylene could be observed in exhaled air depended on the level of exposure; in a few cases (TWA $<10 \mathrm{ppm}$ ) concentrations were below detectable limits already $16 \mathrm{~h}$ after exposure.

\section{Excretion of methylhippuric acid in the urine}

Biotransformation of xylene to methylhippuric acid, and further excretion of
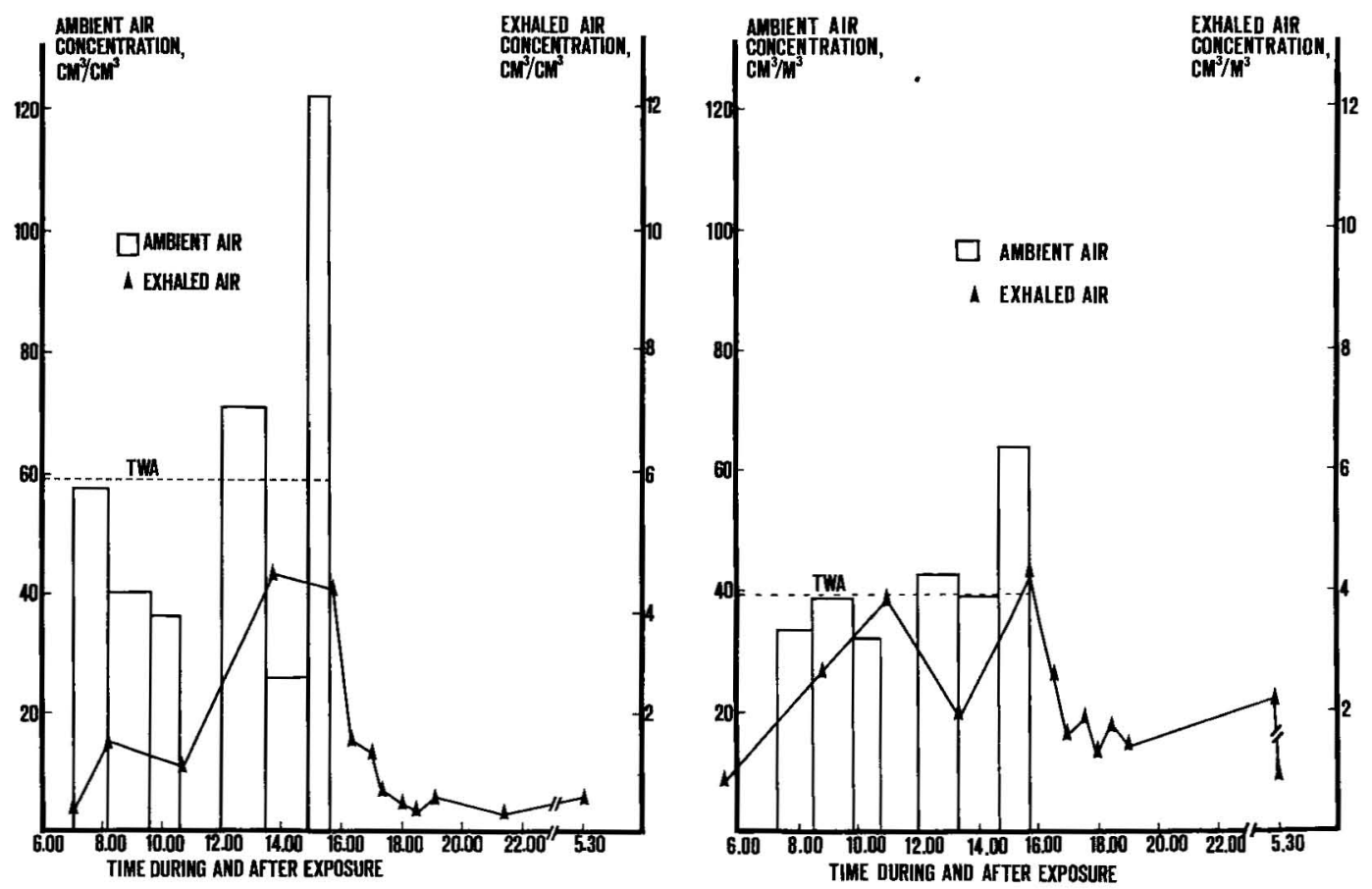

Fig. 2. Xylene concentrations $\left(\mathrm{cm}^{3} / \mathrm{m}^{3}\right)$ of ambient air ( $\square$ ) and exhaled air (A) of two subjects representing workshop $\mathrm{E}$ during and after exposure. Characteristics of the subjects: (a) body height $180 \mathrm{~cm}$, body weight $79 \mathrm{~kg}$, painting by dipping (figure on the left); (b) body height 172 $\mathrm{cm}$, body weight $82 \mathrm{~kg}$, painting by spraying (figure on the right). 
Table 2. Postexposure xylene concentrations in blood and exhaled air.

\begin{tabular}{|c|c|c|c|c|c|c|c|c|c|c|}
\hline \multirow{4}{*}{$\begin{array}{l}\text { Time } \\
\text { after } \\
\text { exposure }\end{array}$} & \multirow{4}{*}{ Sample } & \multicolumn{9}{|c|}{ TWA ${ }^{a}$ xylene concentration during work } \\
\hline & & \multicolumn{3}{|c|}{$1-20 \mathrm{ppm}$} & \multicolumn{3}{|c|}{$21-40 \mathrm{ppm}$} & \multicolumn{3}{|c|}{$41-70 \mathrm{ppm}$} \\
\hline & & \multirow{2}{*}{$\begin{array}{c}\text { Number } \\
\text { of } \\
\text { subjects }\end{array}$} & \multicolumn{2}{|c|}{$\begin{array}{c}\text { Xylene concen- } \\
\text { tration }(\mu \mathrm{g} / 1)\end{array}$} & \multirow{2}{*}{$\begin{array}{l}\text { Number } \\
\text { of } \\
\text { subjects }\end{array}$} & \multicolumn{2}{|c|}{$\begin{array}{c}\text { Xylene concen- } \\
\text { tration }(\mu \mathrm{g} / 1)\end{array}$} & \multirow{2}{*}{$\begin{array}{c}\text { Number } \\
\text { of } \\
\text { subjects }\end{array}$} & \multicolumn{2}{|c|}{$\begin{array}{l}\text { Xylene concen- } \\
\text { tration }(\mu \mathrm{g} / 1)\end{array}$} \\
\hline & & & Mean & Range & & Mean & Range & & Mean & Range \\
\hline \multirow{2}{*}{$\begin{array}{l}1 \mathrm{~min} \\
1 \mathrm{~min}\end{array}$} & Blood & 5 & 256 & $70-460$ & 5 & 434 & $330-620$ & 5 & 874 & $310-1360$ \\
\hline & $\begin{array}{l}\text { Exh: } \\
\text { air }\end{array}$ & 12 & 4.6 & $0.4-8.2$ & 13 & 9.8 & $3.3-18.9$ & 5 & 17.8 & $12.7-45.6$ \\
\hline \multirow{2}{*}{$\begin{array}{l}90 \mathrm{~min} \\
90 \mathrm{~min}\end{array}$} & Blood & 5 & 72 & $30-140$ & 5 & 218 & $160-330$ & 5 & 248 & $190-370$ \\
\hline & air & 12 & 2.0 & $0.2-4.9$ & 13 & 3.5 & $1.0-8.9$ & 5 & 3.5 & $3.2-4.0$ \\
\hline \multirow{2}{*}{$\begin{array}{l}180 \mathrm{~min} \\
180 \mathrm{~min}\end{array}$} & Blood & 5 & 44 & $20-70$ & 5 & 120 & $40-250$ & 5 & 168 & $110-270$ \\
\hline & Exhaled & & & & & & & & & \\
\hline \multirow{2}{*}{$\begin{array}{l}960 \text { min } \\
960 \min \end{array}$} & Blood & $\begin{array}{r}12 \\
5\end{array}$ & $\begin{array}{l}1.0 \\
30\end{array}$ & $\begin{array}{c}0.1-2.6 \\
10-50\end{array}$ & $\begin{array}{r}13 \\
5\end{array}$ & $\begin{array}{r}2.4 \\
60\end{array}$ & $\begin{array}{c}0.7-6.1 \\
40-80\end{array}$ & $\begin{array}{l}5 \\
5\end{array}$ & $\begin{array}{r}3.4 \\
73\end{array}$ & $\begin{array}{c}1.4-6.1 \\
40-160\end{array}$ \\
\hline & Exhaled & 2 & 8 & 01 & 13 & $2 ?$ & 5 & 5 & 49 & ar a \\
\hline
\end{tabular}

a TWA $=$ Time-weighted average.

Table 3. Biologicai half-times of xylene.

\begin{tabular}{lcc}
\hline \multirow{2}{*}{$\begin{array}{l}\text { Body } \\
\text { constitution }\end{array}$} & \multicolumn{2}{c}{$\begin{array}{c}\text { Half-times of methylhippuric } \\
\text { acid (h) }\end{array}$} \\
\cline { 2 - 3 } & Rapid phase & Slow phase \\
\hline \multirow{3}{*}{ Thin } & 1.9 & 16.5 \\
Normal & 2.3 & 22.8 \\
& 2.4 & 19.3 \\
& 2.9 & 29.5 \\
& 3.1 & 24.3 \\
& 3.1 & 39.4 \\
& 3.3 & 26.7 \\
& 3.5 & 29.4 \\
& 3.8 & 24.8 \\
Obese & 4.0 & 33.0 \\
& 4.3 & 27.9 \\
& 4.4 & 36.9 \\
& 3.9 & 32.2 \\
\hline
\end{tabular}

Table 4. Methylhippuric acid concentration in Monday morning urine samples of the first, second and third work week after a month's vacation.

\begin{tabular}{cccc}
\hline & \multicolumn{3}{c}{$\begin{array}{c}\text { Methylhippuric acid concentration } \\
\text { (mg/g creatinine) }\end{array}$} \\
\cline { 2 - 4 } Subject & $\begin{array}{c}\text { First } \\
\text { week }\end{array}$ & $\begin{array}{c}\text { Second } \\
\text { week }\end{array}$ & $\begin{array}{c}\text { Third } \\
\text { week }\end{array}$ \\
\hline \multirow{2}{*}{1} & 2 & 26 & 24 \\
2 & 2 & 14 & 7 \\
3 & 2 & 9 & 28 \\
\hline
\end{tabular}

a After a one-month vacation with no xylene exposure.

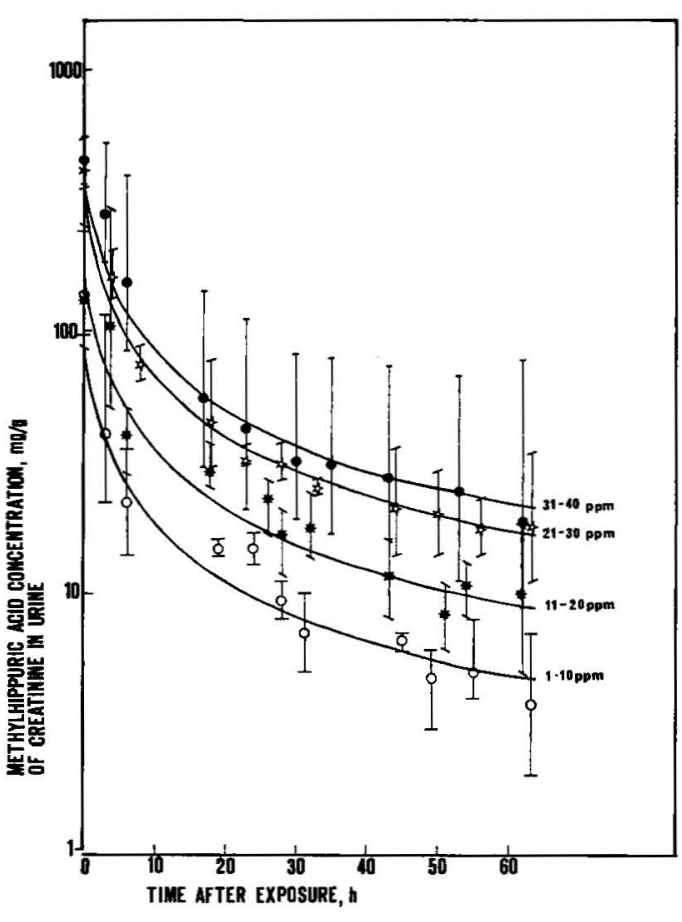

Fig. 3. Postexposure urinary excretion of methylhippuric acid following exposures at $1-10,11-20,21-30$ and $31-40$ ppm (timeweighted average of exposure during three preceding days). The equations were estimated as: $1-10 \mathrm{ppm}$ : in $\mathrm{C}=4.9-0.8 \ln (\mathrm{t}+1)(\mathrm{Ogeo-}$ metric mean for 3 subjects); $11-20 \mathrm{ppm}$ : In $\mathrm{C}$ $=5.5-0.8 \ln (\mathrm{t}+1)$ (* geometric mean for 4 subjects); $21-30$ ppm: $\ln \mathrm{C}=6.2-0.8 \mathrm{In}(\mathrm{t}+$ 1) ( $\{$ geometric mean for 3 subjects); $31-40$ ppm: $\ln \mathrm{C}=6.4-0.8 \ln (t+1)$ geometric mean for 4 subjects). 
the metabolite in the urine, was rapid. High concentrations of methylhippuric acid appeared in the urine already $3 \mathrm{~h}$ after the start of exposure, and rapid elimination continued up to about $10 \mathrm{~h}$ after the termination of exposure. During the following two days excretion of methylhippuric acid took place at a smaller and more constant rate. The mean biological half-times were $3.6 \pm 0.9 \mathrm{~h}$ (range $1.9-5.3 \mathrm{~h}$, $\mathrm{N}=15$ ) for the rapid phase and $30.1 \pm 8.6 \mathrm{~h}$ (range 16.5-48.4 $h$ ) for the less steep one. The variability in the excretion rate was connected to body constitution. Thus, e.g., the values for the thin subject were as follows: rapid $1.9 \mathrm{~h}$; slow $16.5 \mathrm{~h}$; and for the three slightly obese subjects 5.1 and $48.4 \mathrm{~h}, 5.3$ and $40.8 \mathrm{~h}, 3.9$ and $32.2 \mathrm{~h}$, respectively (table 3 ). The last values represent a worker with a low exposure level of xylene. The values for those subjects classified as being normal weight were between 2.3 and $4.4 \mathrm{~h}$ for the rapid phase and between 19.3 and $36.9 \mathrm{~h}$ for the slow one. The corresponding clearance curves are graphically shown in fig. 3, in which the geometric mean and range values are marked for the postexposure urinary excretion of methylhippuric acid following exposures at $1-10$, $11-20,21-30$ and $31-40 \mathrm{ppm}$ (TWA of three preceding days of exposure), respectively. The level of methylhippuric acid in Monday morning urine samples following a month's leave from exposure was smaller after the first week of exposure than after the two succeeding weeks, the prevailing ambient air concentration being on the order of $20 \mathrm{ppm}$. The increase of the methylhippuric acid concentration in the Monday morning urine samples suggests a cumulation of xylene in the body (table 4), which is consistent with the relatively long half-time $(31.0 \mathrm{~h})$ observed for the second excretion phase of methylhippuric acid.

Correlation between urinary methylhippuric acid and the time-weighted average xylene exposure

A high positive correlation was observed between the methylhippuric acid concentration ( $\mathrm{mg} / \mathrm{g}$ creatinine) in samples representing the urine of the last 4 to $5 \mathrm{~h}$ of

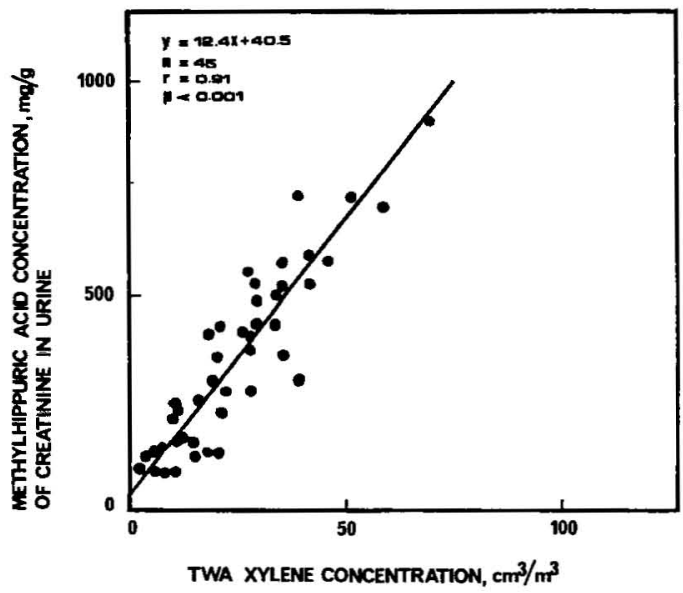

Fig. 4. Correlation between urinary methylhippuric acid concentration ( $\mathrm{mg} / \mathrm{g}$ of creatinine) and the time-weighted average (TWA) of xylene exposure $\left(\mathrm{cm}^{3} / \mathrm{m}^{3}\right)$.

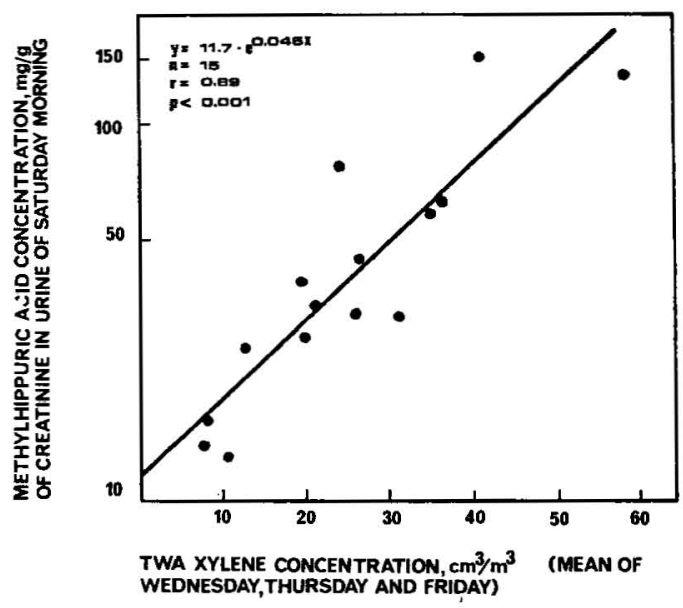

Fig. 5. Correlation between urinary methylhippuric acid concentration ( $\mathrm{mg} / \mathrm{g}$ of creatinine) of the Saturday morning sample and the time weighted-average (TWA) of xylene exposure $\left(\mathrm{cm}^{3} / \mathrm{m}^{3}\right.$, mean of Wednesday, Thursday and Friday). (Log-lin scale)

the workshift and the TWA of xylene exposure ( $\mathrm{r}=0.91, \mathrm{p}<0.001, \mathrm{~N}=45$ ) (fig. 4). For samples representing the urine excreted in the course of the whole workshift, the corresponding correlation gave a similar coefficient $(\mathrm{r}=0.92)$. The distribution of the results is larger if the metabolite concentrations are expressed as milligrams per liter, adjusted to a density of $1.018(r=0.86)$, and still larger if expressed as milligrams per hour $(r=0.80)$. The urinary excretion of methylhippuric acid on the first morning (Saturday) after a 
work week highly correlated to the mean TWA of xylene exposure during the three preceding days $(\mathrm{r}=0.89, \mathrm{p}<0.001, \mathrm{~N}=15)$ (fig. 5). Poor correlation ( $\mathrm{r}=0.66, \mathrm{p}<0.01$, $\mathrm{N}=15$ ) existed however between the TWA xylene exposure of Friday and the methylhippuric acid concentration in the urine the next morning.

\section{DISCUSSION}

In occupational exposure the main route of xylene absorption is the lungs, the retention being 60 to $64 \%(1,8)$. Skin contamination by liquid xylene allows penetration also through the skin and may thus increase the absorbed dose (4). The biotransformation of the retained xylene almost quantitatively $(>95 \%$ ) produces one metabolite, toluic acid, which conjugates to glycine before being excreted in the urine as methylhippuric acid (8). The excretion of free xylene is negligible, and the amount of unchanged xylene eliminated by the lungs is approximately $5 \%$ (8).

Theoretically the analysis of methylhippuric acid in the urine provides a suitable method for evaluating occupational xylene exposure. Methylhippuric acid is the only major metabolite of xylene, and normal urine contains no methylhippuric acid. The relation between urinary methylhippuric acid concentrations and airborne xylene concentrations seems to be dependent on how the amount of the metabolite is expressed. Sedivec and Flek (9) have extensively studied different possibilities for recalculating methylhippuric acid excretion and have shown that individual ventilation is an important determinant. The smallest dispersion in the data was obtained by the use of the total amount of metabolite excreted within $8 \mathrm{~h}$, recalculated to unit lung ventilation.

According to fig. 4 an exposure to 50 ppm of xylene produces a urinary methylhippuric acid content of $665 \mathrm{mg} / \mathrm{g}$ of creatinine in samples collected at the end of the workday. This value is about 100 $\mathrm{mg} / \mathrm{g}$ of creatinine lower than the biological limit proposed by Sedivec and Flek (9) for an 8-h exposure to $46 \mathrm{ppm}$. The difference can be ascribed to the 10 to $15 \%$ too high airborne xylene concentrations (percentage of orto-xylene in the technical product), because our urinary excretion measurements ignore the absorbed ortoisomer. This difference can also be seen when our results are compared to those of Ogata et al. (6).

Due to its great lipid solubility, xylene shows high blood/air ratios as well as a special affinity for adipose tissue. In the rabbit, the blood/air partition coefficient is 37 , and the one for retroperitoneal fat/ blood 146, as determined by Sato et al. (7). This affinity implies that xylene has a tendency to accumulate in fat, as indicated by the observed accumalation from one week to another (table 4). This fact is furthermore underlined by the pattern and the biological half-times for the urinary elimination of xylene found in our study (fig. 3). A sharp initial slope about $10 \mathrm{~h}$ long is followed by a less steep one, which continues up to $63 \mathrm{~h}$ and reflects the release of xylene from storage sites. Sampling during this second phase $(10-63 \mathrm{~h})$ will therefore provide means to evaluate the body burden of xylene. This phenomenon is clearly illustrated in fig. 3 , where the elimination curves run at different levels depending on the level of exposure. Another example of this relationship is shown in fig. 5 , which presents the correlation between the methylhippuric acid concentration of Saturday morning and the mean TWA of xylene exposure during the three preceding days. The regression in fig. 5 shows an exponential pattern (log-lin scale), which may depend on the variation in the elimination pattern at the different exposure levels seen in fig. 3. The time needed for the rapid excretion is shorter at lower than at higher levels of exposure and results in a relatively larger metabolite concentration at that time of sampling, which is presented in fig. 5.

Exhaled air sampling during the workday may be used for the estimation of momentary exposure. The great variability in the recorded results (1 to $27 \%$ of the airborne xylene concentrations), suggests however the influence of other factors. Marked fluctuations in airborne concentrations seem to be a determinant factor, the peak concentration in inspired air in fig. 2 a, e.g., is not reflected in the xylene concentration of corresponding ex- 
haled air samples. Individual variations in the results comparing the thin subject to the slightly obese ones suggest that body constitution has some influence. Thus, the mean value for the thin subject was $14 \%$, whereas the averages of the slightly obese were all below $6 \%$. The corresponding values of the normal weight subjects were between 4 and $12 \%$.

Neither exhaled air samples nor venous blood taken at given intervals after the termination of exposure provided particularly accurate information of the average amount of xylene in ambient air during the preceding workday, due to the overlapping of individual values between the different groups (table 2). The variations were the greatest for the blood/ breath sample taken immediately after the termination of exposure. In our opinion the best time for collection is the 2- to $3-\mathrm{h}$ postexposure interval when the solvent is being released at a more uniform rate, from several tissue compartments, and the analytical detection limit is not yet a problem. It should be noted that in some cases the concentration of xylene in the exhaled air is clearly higher the next morning when compared to the evening sample of the preceding day. Although the results naturally seem to correlate with airborne concentrations only on a group basis, the data should be noted as important individual values. Concentrations found in the exhaled air and in the blood result in the inevitable conclusion that exposure has occurred, and an explanation must always be found for an excessive value.

\section{CONCLUSIONS}

On the basis of this study we recommend a determination of methylhippuric acid concentration in urine samples collected at the end of the workday for evaluating the average xylene exposure during the preceding day. The concentration of methylhippuric acid in a morning sample at the end of the work week provides, on the other hand, a rough estimation of the xylene load of the preceding week. Exhaled air measurements during exposure can be used to supplement ordinary ambient air measurements. The use of exhaled air and blood samples taken after exposure is recommendable only on a group basis, and the best time for sampling is about $3 \mathrm{~h}$ after the termination of exposure. If the methods are used for the biological monitoring of painters, the total existing solvent hazard must not be forgotten.

\section{ACKNOWLEDGMENTS}

The authors wish to thank Sisko Asp, M.Sc., for making the statistical calculations. We wish also to thank Ms. H. Järventaus, Ms. K. Lappalainen, Ms. P. Toropainen, Ms. R. Wirmoila, Mr. P. Mäkelä, and Mr. J. Reponen for their skillful technical assistance.

\section{REFERENCES}

1. BARDODEJ, Z. A study of absorption, metabolism and excretion of toxic vapours. Acta univ. carol. med. 19 (1964) 47-54.

2. CIBA-GEIGY LTD. Scientific tables. Basle 1973 , p. 712.

3. ENGSTRÖM, K., HUSMAN, K. and RANTANEN, J. Measurement of toluene and xylene metabolites by gas chromatography. Int. arch. occup. environ. health 36 (1976) $153-160$.

4. ENGSTRÖM, K., HUSMAN, K. and RIIHIMÄKI, V. Percutaneous absorption of m-xylene in man. Int. arch. occup. environ. health 39 (1977) 181-189.

5. MIKULSKI, P. I., VIGLUSZ, R., BUBLEWSKA, A. and USELIS, J. Investigation of exposure of ships' painters to organic solvents. Br. j. ind. med. 29 (1972) 450 453.

6. OGATA, M., TOMOKUNI, $K$. and TAKATSUKA, Y. Urinary excretion of hippuric acid an $\mathrm{m}$ - or p-methylhippuric acid in the urine of persons exposed to vapours of toluene and $\mathrm{m}$ - or $\mathrm{p}$-xylene as a test of exposure. $B r . j$. ind. med. 27 (1970) $43-50$.

7. SATO, A., FUJIWARA, Y. and NAKAJIMA, T. Solubility of benzene, toluene and $\mathrm{m}$-xylene in various body filuids and tissues of rabbits. Jpn. $j$. ind. health 16 (1974) $30-31$.

8. SEDIVEC, V. and FLEK, J. The absorption, metabolism, and excretion of xylenes in man. Int. arch. occup. environ. health 37 (1976) 205-217.

9. SEDIVEC, V. and FLEK, J. Exposure test for xylenes. Int. arch. occup. environ. health 37 (1976) 219-232.

10. - Finnish import and export of chemical products in 1976. Kem. kemi 4 (1977) 315$326,343-345$.

Received for publication: 7 April 1978 